\title{
EKSISTENSI SASTRA CYBER DI ERA DIGITAL
}

\author{
Nina Ayu Kumala Dewi \\ Universitas Pamulang \\ aninayukd12@gmail.com
}

\begin{abstract}
ABSTRAK
Karya sastra dikenal sebagai produk budaya yang telah melewati setiap zaman perkembangan umat manusia, dari zaman lisan (ketika cerita juga mitos disampaikan dari mulut ke mulut), zaman tulisan, tradisi cetak, dan saat ini di era informasi berbasis teknologi digital. Kemajuan teknologi di era digital ini sangat pesat sehingga mempermudah penyebaran informasi di seluruh dunia, termasuk Indonesia melalui internet. Dewasa ini internet bukan hal yang asing di telinga kita. Bahkan mayoritas, menjadikan internet sebagai kebutuhan yang tidak bisa ditinggalkan. Disamping perkembangan teknologi yang semakin pesat dan canggih, dunia kesasastraan pun juga mengalami perkembangan dan ikut bergerak ke ranah yang modern pula. Sehingga sastra ikut menyesuaikan diri dan terkena dampak internet. Hal ini dapat dilihat dari munculnya istilah-istilah baru, seperti sastra cyber yang semakin popular seiring berkembanganya zaman. Sastra cyber dapat dikatakan sebagai sastra yang ditulis menggunakan media internet atau teknologi informatika lainnya. Sastra cyber ini dijadikan sebagai wahana untuk berkreasi di bidang sastra yang dapat dilakukan oleh siapa pun. Lalu sejak kapan sastra cyber ini muncul? Dan bagaimana kualitas karya dalam sastra cyber?. Sastra menjadi milik bersama, tanpa adanya "monopoli" sastrawan, ahli sastra, atau penulis-penulis ternama. Setiap orang dapat menulis puisi, fiksi, dan bentuk sastra lainnya di internet. Selain menjadi kegiatan individual, para pegiat sastra cyber ini juga membentuk komunitas untuk dapat saling mengapresiasi, baik di dalam situs, blog, atau media social seperti Instagram, Facebook, Twitter, dan lainnya. Tulisan ini ingin menyajikan bagaimana sejarah perkembangan sastra cyber, kualitas serta kelebihan dari sastra cyber itu sendiri.
\end{abstract}

Kata kunci : sejarah, sastra cyber, kualitas dan kelebihan.

\section{PENDAHULUAN}

Seiring dengan berkembangnya zaman, sastra terus mengalami inovasi dan berkembang serta menyesuaikan diri dengan era dimana ia berada. Hal ini dapat dilihat dari munculnya istilah-istilah baru, seperti sastra cyber yang semakin popular. Sastra cyber dapat dikatakan sebagai sastra yang ditulis menggunakan media internet atau teknologi informatika lainnya. Sastra cyber ini dijadikan sebagai wadah dan wahana untuk berkreasi dibidang sastra yang dapat dilakukan oleh siapapun. Bahkan dengan berkembangnya sastra cyber ini memberi keuntungan bagi para penulis atau sastrawan untuk memublikasikan karyanya. (Firtiyani, 2018: 69) mengemukakan bahwa sastra cyber muncul sebagai jawaban atas kegelisahan para penulis pemula dan sastrawan. Sastra cyber ini menjadi wadah penyalur segala bentuk inspirasi bagi penulis pemula yang menjadi tongak baru atas kehadiran sastra yang bersifat 'bebas' tak mengenal ruang, waktu, bahasa dan mendobrak sekat-sekat Negara sehingga tulisan yang dimuat dengan cepat terekspos ke seluruh belahan dunia. Kemunculan sastra lahir dilatar 
belakangi adanya dorongan dasar manusia untuk mengungkapkan eksistensi dirinya. (dalam Sarjidu, $2004: 2)$.

Namun, ditengah perkembangan teknologi yang semakin pesat ini, sastra cyber juga tidak pernah lepas menuai kontroversi (pro dan kontra). Dari kalangan ahli sastrapun banyak yang mendiskusikan hal ini dengan berbagai pandangan. Ada yang menilai positif dan juga menilai negatif. Fenomena sastra cyber di Indonesia agaknya membutuhkan perhatian yang lebih besar lagi karena dipercaya dapat berkontribusi bagi perkembangan kesusastraan di Indonesia. Tidak hanya itu, keberadaan sastra cyber sendiri dipercaya sebagai refleksi realitas dinamika masyarakat yang ada saat ini. Masyarakat yang senantiasa bergerak ke arah yang lebih modern ikut memberikan kontribusi bagi kemunculan sastra cyber dengan mengikuti pesatnya perkembangan teknologi komputer dan internet yang ada.

Sastra tak melulu dalam bentuk yang sering disandarkan padanya yakni bersifat konvensional, melainkan juga turut mengambil tempat dalam khazanah kehidupan modern yang semakin kompleks. Pada dasarnya sastra merupakan ciptaan sebuah kreasi, bukan semata-mata sebuah imitasi (dalam Luxemburg, 1989 : 5). Karya sastra sebagai bentuk dan hasil sebuah pekerjaan kreatif pada hakikatnya adalah suatu media yang mendayagunakan bahasa untuk mengungkapkan tentang kehidupan manusia. Oleh sebab itu, sebuah karya sastra, pada umumnya, berisi tentang permasalahan yang melingkupi kehidupan manusia.

\section{METODE PENELITIAN}

Penelitian ini menggunakan studi kualitatif dengan menerapkan metode analisis deskriptif, yang bertujuan untuk mendeskripsikan penelitian berdasarkan data-data yang dianalisis. Teknik yang digunakan adalah dengan cara mengumpulkan data dari fakta yang ada dan beberapa sumber dokumen. Penelitian ini pula berusaha untuk mengumpulkan informasi untuk menjawab pertanyaan peneliti dengan memperhatikan aspek-aspek yang didapatkan dari banyak data-data penelitian, sehingga dapat menggambarkan suatu kondisi, peristiwa, atau fenomena dengan spesifik dan urut.

\section{PEMBAHASAN}

Istilah sastra cyber mulai populer memang baru beberapa dekade terakhir. Lebih tepatnya pada saat budaya internet tumbuh berkecamuk di Indonesia. Hidayat (2008: 261) menyatakan bahwa munculnya sastra Cyber dimulai berdasarkan kemajuan ilmu pengetahuan dan teknologi yang kian merambah di berbagai segi kehidupan. Akan tetapi, pada dasarnya hal itu dimulai dari akal diri manusia, yang telah mendorong berbagai fonemena untuk dianalisis berdasarkan nalar sehingga memunculkan rasionalitas dan fungsionalitasnya. Dengan kemampuan tersebut, manusia dengan seksama mempelajari berbagai ilmu pengetahuan yang ada di dunia. Salah satu implementasinya adalah penemuan yang mencangkup Ilmu Pengetahuan dan Teknologi (Iptek). Perkembangan sastra cyber di Indonesia mulai dikenal oleh khalayak di akhir tahun 1990-an dan ditandai dengan peluncuran buku antologi puisi cyber 
berjudul Graffiti Gratitude pada tanggal 9 Mei 2001 di Puri Jaya, Hotel Sahid, Jakarta yang digawangi oleh Sutan Ikwan Soekri Munaf, Nanang Suryadi, Nunuk Suraja, Tulus Widjarnako, Cunong, dan Medy Loekito. Mereka tergabung dalam satu yayasan yaitu Yayasan Multimedia Sastra (YMS). Kemunculan buku tersebut menuai pro dan kontra di kalangan masyarakat yang bergelut di bidang sastra, bahkan peluncuran antologi ini sempat mengundang kritikan, baik terhadap wujud bukunya maupun terhadap kualitas puisinya. Namun, hal itu tidak membuat Usman K.J Suharjo (2001) urung mengusulkan agar hari peluncuran buku antologi puisi cyber tersebut diperingati sebagai hari Sastra Cyber Indonesia.

Endraswara (2013: 182-183) memaparkan definisi sastra cyber bermula dari kata cybersastra yang dapat dirunut dari asal katanya yakni cyber, yang dalam bahasa Inggris tidak bisa berdiri sendiri, melainkan terjalin dengan kata lain seperti cyberspace, cybernate dan cybernetics. Cyberspace berarti ruang (berkomputer) yang saling terjalin membentuk budaya di kalangan mereka. Cybernate berarti pengendalian proses menggunakan komputer. Cybernetics yakni mengacu pada sistem kendali otomatis, baik dalam sistem komputer (elektronik) maupun jaringan syaraf. Biasanya sastra cyber berupa karya sastra yang bergenre puisi atau prosa.

Dari pengertian ini, dapat dikemukakan bahwa cybersastra atau sastra cyber adalah aktivitas sastra yang memanfaatkan komputer atau internet. Juga sastra cyber dapat dikatakan sebagai karya sastra yang dipublikasikan pada media daring seiring perkembangan ilmu pengetahuan dan teknologi di berbagai negara di dunia. Internet seolah memberikan iklim kebebasan yang hakiki, tanpa sensor. Semua orang boleh memajang karyanya dan boleh mengapresiasinya dari berbagai penjuru di dunia. Kebutuhan besar para pegiat sastra untuk berkarya dan memublikasikan karyanya menemukan titik terang dengan adanya internet sebagai ruang sosialisasi tanpa batas. Sastra cyber dapat dijadikan sebagai perlawanan atas legitimasi bahwa kapabilitas seorang sastrawan ditentukan oleh kemampuannya menembus media massa. Seorang sastrawan dikatakan sastrawan internasional apabila karyanya pernah muncul di media massa bertaraf internasional. Adanya sastra cyber dan seiring perkembangannya, sangat menguntungkan bagi para penulis atau sastrawan pemula untuk memublikasikan karyanya. Hal tersebut dimaklumi karena pada masa sebelum tahun 2000-an tidak mudah untuk dapat memublikasikan karya sastra pada penerbit atau di media mainstream. Bahkan (Fitriani, 2018: 69) mengemukakan bahwa Sastra cyber atau cyber sastra muncul menjawab kegelisahan para penulis atau sastrawan pemula. Sastra cyber atau Cybersastra ini dijadikan sebagai wahana penyalur segala bentuk inspirasi, aspirasi bagi penulis pemula yang menjadi tonggak baru kehadiran dunia sastra yang sifatnya 'bebas' tak mengenal ruang, waktu, bahasa, dan mendobrak sekat-sekat negara, karena dengan beberapa detik tulisan yang dimuat akan terekspos ke seluruh belahan negara.

Terlepas pada permasalahan pro dan kontra tersebut, bahwa saat ini telah muncul genre sastra baru yakni sastra cyber. Sastra cyber seperti Wattpad, PlukMe, Cabaca, Mangatoon dan Webtoon bisa menjadi wadah untuk menyalurkan bakat menulis. Platform sastra cyber terbuka bagi siapa pun untuk 
membuat akun dan menulis di akun miliknya. Peran pembaca terhadap cerita yang ditulis menjadi hal yang menarik. Secara umum karya sastra cyber memiliki karakter yang berbeda dengan karya sastra yang di terbitkan melalui media cetak. Karakter dan sosiologi penulis mempengaruhi karakter karya sastra cyber yang dihasilkan. Selain itu, penciptaan karya sastra cyber memiliki motif kapitalis yang berujung pada pencapaian keuntungan finansial dan sebagai usaha pencapaian eksistensi penulisnya.

\section{KUALITAS}

Meski sudah hadir lebih dari satu dekade, sejak tahun 2000, sastra cyber semakin menunjukan inovasi dalam bersastra. Para pegiat sastra cyber ini kian berkembang dengan bertahannya situs social media dan maraknya penggunaan blog. Mengenai kualitas terhadap karya sastra yang lahir dari sastra cyber ini masih menjadi hal yang diperdebatkan oleh banyak sastrawan dan ahli sastra. Kualitas sastra cyber dianggap tidak sejajar dengan karya sastra hasil sastrawan yang karyanya berlabel sastra popular dipasaran.

Ahmadun Yosi Herfanda menyebut bahwa sastra cyber tidak ubahnya tong sampah. Ahmadun menyebut bahwa pegiat sastra cyber adalah penulis yang gagal masuk koran karena karyanya tidak diterima. Sedangkan, Maman S. Mahayana menyebut penulis puisi cyber tidak pantas disebut penyair, karena tidak jelasnya produktivitas para penulisnya. Pendapat yang lebih sarkartis diutarakan Sutardji Calzoum Bahri saat menanggapi Graffiti Gratitude. Dia menyebut, tai yang dibungkus dengan menarik akan lebih laku dibanding puisi yang dibungkus secara asal-asalan. Kalimat yang dimaksud sebagai analogi terhadap puisi cyber.

Meski demikian, apresiasi positif juga diberikan oleh sastrawan lainnya. Salah satunya oleh Seno Gumira Ajidarman dalam pengantarnya pada sebuah buku antologi puisi cyber 'Bunga Matahari. Begitu juga Jamal D. Rahman, penyair yang juga redaktur majalah sastra Horison, menyebut bahwa komunitas yang menyandarkan kegiatannya di dunia maya itu membuka kemungkinan bagi sosialisasi sastra lebih jauh sebagai apresiasi positif terhadap sastra cyber.

Mengenai kualitas karya sastra pada sastra cyber, siapakah yang layak untuk menilai baik dan buruknya?. Baik buruknya kualitas sebuah karya sastra hanya dapat dijawab oleh waktu dan pembacanya. Apakah karya tersebut hanya menjadi hiburan saja atau memang merupakan suatu karya yang memiliki suatu nilai, sehingga bertahan dimemori pembacanya. Namun, dalam menilai suatu karya sastra pengetahuan yang mumpuni tetap dibutuhkan untuk menilai karya sastra tersebut.

Pada akhirnya, sastra cyber tidak dapat dipungkiri menjadi bagian dari sejarah sastra Indonesia. Keberadaan sastra cyber merupakan reaksi positif dunia sastra dalam menyongsong kemajuan teknologi. Media internet dan teknologi informatika lainnya hendaknya menjadi media yang dapat digunakan untuk berkarya dan mengenalkan sastra kepada masyarakat luas. 


\section{KELEBIHAN}

Kemunculan sastra cyber memang memunculkan polemik serta pro dan kontra, baik dikalangan pemerhati sastra, penikmat sastra dan ahli sastra. Namun, terlepas dari berbagai kritik dan polemik tersebut, fakta menunjukkan bahwa sastra cyber ini adalah sastra dengan genre baru. Kehadiran sastra cyber ini, sebenarnya tidak jauh berbeda dengan berkembangnya medium untuk menulis atau membuat blog di internet.

Ruang cyber memberikan banyak manfaat bagi semua lapisan masyarakat. Ditambah dengan penggunaan social media yang kian hari menaik dan tidak lepas dari bebagai aktivitas. Ruang cyber selain bermanfaat untuk sarana informasi dan sosialisasi, juga bermanfaat sebagai ladang untuk berkarya. Seperti yang kita ketahui, saat ini semakin banyak aplikasi atau platform digital yang cukup mendukung untuk berbagi tulisan, mengasah kemampuan dan menuangkan berbagai ide. Bahkan kerap menulis di media menjadi salah satu tugas yang diberikan sebagai tugas akhir atau tambahan nilai. Manakala sebuah karya sastra/tulisan diunggah, karya tersebut akan dengan mudahnya diakses oleh siapapun. Beberapa kelebihan dari adanya sastra cyber yakni, lebih bebas berekspresi, dapat menghasilkan suatu karya, peluang menuangkan ide dan forum silaturrahmi akan lebih mudah terjalin. Pembaca dapat langsung mengkritik dan mengomentari karya tersebut.

Hal ini berbeda dengan sastra dalam artian konvensional yang selama ini kita pahami bersama. Selain kelebihan tersebut, sastra cyber sebenarnya juga memiliki kekurangan, terutama dalam hal fungsi sastra sebagai katalisator dan sebagai alat silaturahmi. Konsep sastra cyber memang tidak memungkinkan siapapun yang terlibat di dalamnya untuk bersemuka atau bertemu langsung. Hal itu yang menyebabkan sastra cyber seolah "jauh" dari hati masyarakat dan lebih cenderung hanya bisa dinikmati secara personal. Pada sastra konvensional, hal itu tidak akan terjadi karena setiap orang yang terlibat di dalamnya dapat bersemuka atau berinteraksi secara langsung.

\section{KESIMPULAN}

Sastra cyber dapat dikatakan sebagai karya sastra yang dipublikasikan pada media daring seiring perkembangan ilmu pengetahuan dan teknologi di berbagai negara di dunia. Semua orang boleh memajang karyanya dan boleh mengapresiasinya. Kebutuhan besar para pegiat sastra untuk berkarya dan memublikasikan karyanya menemukan titik terang dengan adanya internet sebagai ruang sosialisasi tanpa batas. Sastra cyber pula dapat dijadikan sebagai perlawanan atas legitimasi bahwa kapabilitas seorang sastrawan ditentukan oleh kemampuannya menembus media massa. Dengan adanya sastra cyber, semua orang dapat berkontribusi dan memublikasikan karyanya.

Kemajuan teknologi yang pesat semakin mendukung berbagai kebutuhan masyarakat. Ditambah dengan berbagai aplikasi dan platform yang memberi peluang tambahan untuk terus mengembangkan ide dan berbagi wawasan, penelitian serta informasi. Meskipun banyak pihak yang 
masih meragukan akan kualitas dari karya yang lahir dari sastra cyber sendiri, namun tidak dapat dipungkiri sastra cyber sudah menjadi bagian dari sejarah sastra Indonesia. Dengan demikian dapat dikatakan bahwa bahasa dan sastra Indonesia didunia cyber sangat bermanfaat untuk kemajuan pengembangan bahasa dan sastra Indonesia. Apapun tantangannya harus dihadapi dan diatasi.

\section{REFERENSI}

Herfanda, Ahmadun Yosi. 2004. "Puisi Cyber, Genre atau Tong Sampah" dalam Cyber Grafitti: Polemik Sastra Cyber punk, Kumpulan Esai. Saut Situmorang (Editor). Yogyakarta: Jendela.

Santoso, T. (2012, Januari 29). Sastra Cyber. Retrieved Desember 17, 2019, from

Situmorang, Saut. 2004. Cyber Grafiti: Polemik Sastra Cyber. Yogyakarta: Jendela

Endaswara, Suwardi. 2003. Metodologi Penelitian Sastra. Yogjakarta: Pustaka Widyatama.

Komunitas Bunga Matahari. 2008. Antologi Bunga Matahari. Jakarta: Avatar Press.

http:/rakbuku.blogspot.com/2004 0801 rakbukuarchive.html

WWW.Cybersastra.net 